\title{
Fragmentação produtiva, comércio exterior e complexidade estrutural: uma análise comparada entre o Brasil e México a partir de matrizes de insumo-produto
}

\section{Kaio Glauber Vital da Costa \\ Marta dos Reis Castilho \\ Martín Puchet Anyul}

\section{Área temática 2.2: Comércio internacional, cadeias de valor e interncioanlização - Comércio internacional e cadeias de valor}

Resumo: O objetivo do presente estudo é investigar como os diferentes padrões de especialização comercial do Brasil e do México impactaram a complexidade das estruturas produtivas das duas economias entre 1995 e 2011. Busca-se argumentar que, embora os padrões de comércio exterior do Brasil e do México difiram principalmente em termos de suas pautas exportadoras, os processos de abertura comercial e de inserção nas cadeias globais de valor levaram a uma redução na complexidade da rede de interrelações entre os setores. Uma vez que esses países são as duas maiores economias da América Latina, a redução na complexidade de suas estruturas produtivas tem impactos não somente para a dinâmica das respectivas economias domésticas, mas também para a dinâmica das demais economias da região.

Palavras-chave: Fragmentação produtiva; comércio exterior; complexidade; insumo-produto.

\begin{abstract}
The objective of this work is to perform a comparison between two different patterns of trade specialization, Brazil and Mexico, and how these patterns impacted the complexity of the productive structures of both economies between 1995 and 2011. It is argued that although the patterns of foreign trade in Brazil and Mexico differ, mainly in terms of their exporting patterns, the processes of trade openness and insertion in global value chains have led to a reduction in the complexity of the network of interrelations among sectors. Since these countries are the two largest economies in Latin America, the reduction in the complexity of their productive structures can impact not only the dynamics of their respective domestic economies, but also the dynamics of other economies in the region. In order to do the comparison of the structural complexity index, we used the matrices of World Input-Output Database (WIOD).
\end{abstract}

Keywords: Productive fragmentation; International trade; Structural complexity; Input-output.

Código JEL: F1; F12; C67; L15 


\section{Introdução}

A ocorrência de um crescimento econômico sustentado requer uma transformação da estrutura produtiva que seja compatível com a evolução da demanda doméstica e as mudanças no comércio internacional. Isso significa dizer que a estrutura produtiva de um país deve ser capaz de se adaptar às transformações em curso no âmbito doméstico e externo (Chenery, 1980). Nas últimas duas décadas as economias brasileira e mexicana, as duas maiores economias da América Latina, experimentaram profundas transformações em suas estruturas produtivas e em seus padrões de comércio internacional. Estas modificações impactaram diretamente no arranjo e na intensidade das articulações entre os setores, de modo que a complexidade de ambas as estruturas produtivas perderam complexidade estrutural a partir de meados da década de 1990 (Coutinho, 1997; Britto, 2002; Moreno-Brid e Ros, 2010).

Desde a década de 1970 o esgotamento do modelo de industrialização por substituição de importações, baseado no crescimento do mercado interno, induziu as economias da América Latina a se moverem na direção de novos padrões de especialização produtiva e de comércio exterior. Como consequência dessas modificações, se consolidaram dois grandes cenários de especialização produtiva e comercial. O primeiro tem seu epicentro no Cone Sul, com países (como o Brasil) apresentando uma preponderante especialização em setores industriais processadores de recursos naturais. Esses setores são caracterizados pelo uso altamente intensivo de capital. No segundo cenário, o México e outros países da América Central possuem um modelo alternativo de especialização produtiva e comercial, baseado na maquila eletrônica, automotiva e de roupas, dirigidas principalmente ao mercado dos Estados Unidos (Katz, 2000).

Os diferentes padrões de comércio exterior do Brasil e do México mostram, por um lado, uma crescente dependência em relação aos insumos intermediários importados, e, por outro lado, exportações com baixa capacidade de geração de emprego e de renda (Ruiz-Nápoles, 2004; Fujii e Cervantes, 2013; Kupfer et al., 2013). O grande aumento das importações de insumos importados na década de 1990 e ao longo dos anos 2000 estaria relacionado aos processos de abertura comercial, à valorização persistente do câmbio e às estratégias microeconômicas de localização das plantas industriais das empresas transnacionais (doravante, ETNs). O processo de fragmentação produtiva e a consequente formação das cadeias globais de valor $(\mathrm{CGV})$ parecem ter exacerbado os padrões de especialização comercial de ambos os países. Em que pesem os diferentes posicionamentos e graus de participação dos dois países nas CGV (Hermida, 2016; Boddin, 2017), fato é que as respectivas inserções nessas cadeias não foram capazes de modificar seus padrões de comércio exterior (Medeiros e Trebat, 2017). Os setores tradicionalmente exportadores - baseados em recursos naturais (intensivos em capital) e nas maquilas (intensivos em trabalho) - reforçaram suas participações nas exportações totais e no saldo comercial. Por outro lado, os setores que envolvem um maior conteúdo tecnológico tornaram-se crescentemente deficitários (Katz, 2000).

O objetivo do presente estudo é analisar a complexidade das estruturas produtivas do Brasil e do México em um contexto de processos produtivos fragmentados. A complexidade será analisada a partir da abordagem proposta originalmente por Lantner e Lebert $(2013,2015)$, que permite medir o grau de articulação, direta e indireta, entre todos os setores de uma economia. Nesse estudo, uma estrutura mais complexa significa uma maior interdependência entre os setores e, assim, uma maior circularidade dos fluxos de bens e serviços nessas economias. A utilização de um indicador de complexidade estrutural, que leve em consideração toda a rede de inter-relações, diretas e indiretas, entre os setores possibilita um melhor entendimento das estruturas produtivas das duas maiores economias da América Latina. Os estudos comparados entre as economias brasileira e mexicana são poucos, de modo que a presente análise também contribui para as pesquisas comparativas entre as duas economias.

O artigo está estruturado em três seções além da introdução e das conclusões. Na seção 2, desenvolvemos os elementos conceituais relacionados ao processo de fragmentação produtiva e 
complexidade estrutural. Na seção 3, expomos a fonte dos dados e a construção dos indicadores utilizados no estudo. Por fim, na seção 4, apresentamos os resultados.

\section{Fragmentação produtiva e complexidade estrutural: revisão da literatura e considerações conceituais}

O surgimento das cadeias globais/regionais de produção e de valor (doravante, CGV) modificou dramaticamente a organização da produção mundial de bens e serviços nas últimas desde meados da década de 1980 (Baldwin, 2011), provocando impactos mais profundos e duradouros sobre os padrões de comércio internacional e de investimento. O compartilhamento internacional da produção sempre fez parte do comércio internacional, tendo em vista que os países importam bens manufaturados que serão incorporados em suas exportações ${ }^{1}$ (Athukorala e Menon, 2010). Contudo, a redução nos custos dos transportes e das comunicações, a aceleração do progresso tecnológico e redução das barreiras econômicas e políticas ao comércio aumentaram as oportunidades para a fragmentação internacional da produção.

Baldwin (2011) enquadra as grandes transformações ocorridas no comércio internacional nas últimas décadas como uma sequência de desagregações (unbundlings). Até o final do século XIX, as fábricas tinham estruturas de produção verticalmente integradas, nas quais partes e componentes eram produzidas sequencialmente ou em diferentes locais contíguos localizados próximo aos consumidores finais. Ao longo do século XX, a desagregação espacial da produção e as modificações nos padrões de consumo (a primeira desagregação) foram possíveis devido à redução nos custos do transporte, originado pela energia a vapor. Embora a produção já apresentasse algum grau de dispersão geográfica, ainda estava localmente agrupada para minimizar os custos de coordenação. Este paradigma foi substituído pela rede internacional de fornecedores mundiais, que se especializam em fases específicas do processo de produção e estão localizados em diferentes países dispersos geograficamente. A desagregação espacial da produção em estágios previamente agrupados em fábricas (a segunda desagregação) foi beneficiada por uma queda acentuada dos custos de comunicação e coordenação, mudando profundamente a natureza do comércio internacional.

Neste contexto, o aprofundamento da fragmentação produtiva, com a crescente incorporação de países em desenvolvimento, provocou uma redefinição da divisão internacional do trabalho, o qual está alterando a geografia da produção através da deslocalização de determinadas indústrias. Este processo foi orientado principalmente por dois fatores: i) políticas de abertura comercial, tais como a assinatura de acordos regionais (Tratado de Libre Comercio de América del Norte, TLCAN, e Mercosul, por exemplo), e avanços nas tecnologias da infomação e comunicação. O primeiro fator provocou a redução das tarifas e reduziu os obstáculos ao investimento direto estrangeiro. O segundo fator diminuiu os custos de transporte e os custos de coordenação/supervisão das atividades dentro das empresas transnacionais (ETNs) ${ }^{2}$. Como resultado, as ETNs passaram a reorientar suas estratégias de localização de suas indústrias, de acordo com as características de cada região/país, tais como: custos da mão-de-obra, o tamanho do mercado interno ou assuntos regulatórios e institucionais. A redução dos custos de localização no exterior, devido a

\footnotetext{
${ }^{1}$ Pollard (1981) afirma que, no auge da Revolução Industrial, os produtores britânicos de têxtei e vestuários começaram a "deslocar" os segmentos intensivos em trabalho do processo produtivo para países da Europa continental, devido à escassez de mão-de-obra doméstica e crescentes pressões salariais.

${ }^{2}$ Como apontado por Medeiros (2010), a liderança das ETNs nas atividades suscetíveis de serem fragmentadas decorre dos elevados custos de administração e coordenação, que estão implicados no processo de fragmentar geograficamente a produção. Uma das consequências desses elevados custos é a imposição implícita de elevadas barreiras de escala às empresas domésticas.
} 
internacionalização da produção, leva as ETNs a deslocarem algumas plantas de países altamente desenvolvidos para países em desenvolvimento, com menores custos de produção ${ }^{3}$.

$\mathrm{Na}$ literatura sobre $\mathrm{CGV}$, os estudos estão preocupados principalmente com o grau e o posicionamento dos países dentro dessas cadeias (Foster-McGregor e Stehrer, 2013; Timmer et al., 2014; Hermida, 2016; Corrêa, 2016). Nesses estudos, o grau de participação é medido, em geral, pelo conteúdo importado contido nas exportações. Por posicionamento, entende-se a localização de um país nas fases upstream ou downstream das CGV. Os países localizados na fase upstream (Brasil) são caracterizados como fornecedores de matérias-primas, enquanto os localizados na fase downstream são aqueles processadores ou montadores de insumos importados (México). Medeiros (2010, p.260) afirma que a fragmentação da produção e a formação de CGV lideradas pelas ETNs resultam importantes assimetrias entre os países, dependendo em quais fases os países estão especializados, "podendo constituir tanto uma possibilidade de desenvolvimento para os países mais atrasados quanto uma armadilha".

\subsection{A complexidade estrutural como um aspecto particular da articulação interindustrial}

A conectividade é a característica principal da análise insumo-produto e há, como esperado, muitas maneiras de medí-la, desde os estudos pioneiros de Chenery e Watanabe (1958), Rasmussen (1956) e Hirschman (1961) até os modelos mais sofisticados, tais como as medidas de interdependência de Yan e Ames (1965), a transactions rounds matrix de Robinson e Markandya (1973), a medida de ciclicidade de Finn (1976) e a medida de autovalor dominante de Dietzenbacher (1992). Entre os mais recentes exemplos de medidas de interdependência, mostrando o ressurgimento do interesse por esse tipo de pesquisa, estão o comprimento das cadeias produtivas de Romero, Dietzenbacher e Hewings (2009) e a complexidade como uma medida de interdependência entre os setores de Amaral et al. (2007) ${ }^{4}$. Esses estudos estão preocupados principalmente com o nível de articulação ou deinterdependência entre os setores e as análises dos multplicadores setoriais.

De acordo com Basu e Johson (1994), os vários métodos para desenvolver índices a partir das matrizes de insumo-produto podem ser classificados como:

1. Índices baseados nas matrizes de fluxos interindustriais;

2. Índices baseados em matrizes de booleanas ${ }^{5}$;

3. Índices baseados na matriz inversa de Leontief;

4. Índices baseados em abordagens mistas.

Uma vez que a análise interindustrial se ocupa das interrelações necessárias à produção de bens e serviços, a função primordial da análise estrutural é investigar o curso das correntes de bens e

\footnotetext{
${ }^{3}$ Para Sarti e Hiratuka (2010), esses deslocamentos plantas industriais dos países desenvolvidos para os países periféricos foram regionalmente concentradas, especialmente na região asiática (China). A dispersão geográfica da produção resultou em uma concentração nas principais cadeias industriais mundiais, com a consolidação das ETNs no comando dessa reorganização mundial da indústria. Nesse sentido, o movimento de descentralização das atividades produtivas com centralização e concentração do poder de comando sobre o valor gerado por essas atividades foi o resultado da interação entre as mudanças no cenário macroeconômico mundial, reestruturação nas formas de organização e concorrência entre as ETNs.

${ }^{4}$ Esse autores utilizam o termo "complexidade econômica" como o resultado do desenvolvimento das economias, que amplia a multiplicidade das interdependências dentro de um sistema econômico. Sonis e Hewings (1998) definem como o resultado do gradual processo (ou propriedade emergente) de complexificação da rede de interdependências entre os setores econômicos, atividades econômicas e todos os possíveis sub-sistemas econômicos e espaciais. Uma vez que esses estudos utilizam principalmente a abordagem de insumo-produto para analisar os fluxos de trocas presentes nas economias e como uma forma de diferenciar a noção de complexidade econômica presente em Hidalgo et al. (2007) e Gala (2017), é mais apropriado a utilização da noção de complexidade estrutural. A utilização desse termo é também mais apropriada porque o objetivo principal desses indicadores baseados em matrizes de insumo-produto é, de modo geral, medir o grau de interdependência entre os setores que compõem a estrutura produtiva de uma economia.

${ }^{5}$ Uma matriz booleana é uma matriz formada apenas pelos valores 0 e 1 , sendo que 0 indica a inexistência de fluxos entre dois elementos quaisquer em uma matriz de trocas e 1 mostra a existência de fluxos entre esses elementos.
} 
serviços em sua sequência de um setor a outro da estrutura. Assim, o interesse da análise estrutural, desde suas primeiras formulações com Leontief (1985), foi a construção de indicadores que permitissem entender a arquitetura das estruturas produtivas dos países. Ou seja, qual é a dominância de um setor em relação a outro (Hurwicz e Leontief, 1955; Leontief, 1985)? Os setores são mais ou menos auto-suficientes, interdependentes e/ou dependentes entre eles (Sonis e Hewings, 1998)? A estrutura produtiva está mais ou menos conectada com os fluxos de bens e serviços demandados de outras economias (Sonis e Hewings, 2001)?

Dentro dessa abordagem de análise estrutural, Wong (1954) sugere que o determinante da matriz de coeficientes técnicos $\Delta=(I-A)$ é uma medida relativa do volume da produção líquida e da complexidade do sistema produtivo. A abordagem proposta por Lantner $(1972,1974)$ também parte da interpretação dos determinantes da matriz $(I-A)$, mas tem como base os teoremas propostos por Bott e Mayberry (1954). A partir do estudo dos determinantes de matrizes de relações interindustriais ou comerciais, Lantner (1972, 1974), Gazon (1976) e Lantner e Lebert (2013, 2015) elaboram o conceito de circularidade estrutural. O índice de circularidade estrutural busca medir o nível de interdependência entre todo um conjunto de indústrias em um sistema econômico ou entre países/regiões no comércio internacional.

Do ponto de vista quantitativo, o determinante tem a vantagem de ser um indicador sintético que mostra o arranjo interno da estrutura dos setores produtivos ou dos vínculos comerciais entre regiões ou países, isto é, da posição e da intensidade das conexões entre os setores e/ou países. Já do ponto de vista qualitativo, permite interpretar a complexidade das estruturas produtivas como o resultado do gradual processo de expansão da rede de interdependências hierárquicas entre setores da economia. Ademais, é possível realizar uma análide de decomposição estrutural a partir do cálculo dos determinantes, de modo a calcularmos as taxas de interdependência, de dependência e de autarquia das economias ${ }^{6}$.

Formalmente, o índice de circularidade ou de complexidade estrutural é definido como ice $=\frac{(1-\Delta)}{\Delta}$. O índice de complexidade estrutural é um indicador da quantidade de circuitos de retroalimentação que existem entre os setores de uma economia. A presença dos circuitos de retroalimentação indica que as relações entre os setores produtivos são mais densas e que os setores estão mais integrados entre si. A estrutura produtiva fica mais complexa e desenvolvida à medida em que o número de circuitos de retroalimentação aumenta em relação a todos os circuitos que unem todos os setores (Puchet, 1996).

Quando uma estrutura produtiva torna-se mais complexa, no sentido de que todo setor depende cada vez mais dos demais setores como fornecedores de insumos para sua produção, a demanda intermediária aumenta como proporção do produto total e cresce a geração de efeitos de retroalimentação entre os setores. Como apontado por Aroche-Reyes (1993), o índice de complexidade estrutural não depende do tamanho dos coeficientes técnicos, $a_{i j}$, mas da complexidade da estrutura produtiva, definida pela presença de circuitos de retroalimentação entre os setores ou do nível de integração entre os setores. Ao contrário do indicador de complexidade econômica elaborado por Hidalgo et al. (2007), que toma como dado o grau de interdependência entre os setores da estrutura produtiva para analisar a complexidade econômica a partir dos produtos exportados pelos países, o índice de complexidade estrutural é elaborado exatamente a partir da matriz de trocas entre os setores produtivos de uma economia. Essa abordagem permite um melhor entendimento do grau de interdependência entre os setores de uma economia ou de sua complexidade estrutural, uma vez que lança luz sobre o nível de articulação presente na estrutura produtiva.

\footnotetext{
${ }^{6}$ Um critério para estimar, a priori, a importância relativa dos setores de uma estrutura produtiva pode ser formulado determinando-se os sub-determinantes da nova estrutura sem o respectivo setor extraído. Essa extração permite verificar quantitativa e qualitativamente a importância de um setor no processo de intermediação dos fluxos de bens e serviços.
} 


\section{A complexidade estrutural sob o signo da fragmentação produtiva}

Os processos de abertura comercial pelos quais passaram o Brasil e o México entre as décadas de 1980 e 1990 resultaram em dois padrões distintos de especialização comercial. De um lado, o Brasil e os demais países do América do Sul especializados na exportação de produtos baseados em recursos naturais, enquanto, por outro lado, o México com um padrão exportador centrado nas maquilas industriais destinadas em grande parte aos Estados Unidos (Katz, 2000). Além desse efeito pelo lado das exportações, a abertura comercial provocou movimentos de reestruturações industriais em ambos os países, que se refletiram em uma maior dependência em relação aos insumos intermediários importados em quase todos os setores. $\mathrm{O}$ aumento de partes, peças e componentes estaria relacionado às estratégias defensivas das empresas nacionais frente à concorrência estrangeira e à utilização da rede de fornecedores estrangeiros pelas ETNs (Britto, 2002; Kupfer, 2005; Fujii e Cervantes, 2013).

O grande aumento das importações de insumos importados na década de 1990 e ao longo dos anos 2000 estaria relacionado ao processo de abertura comercial, à valorização persistente do câmbio e às estratégias microeconômicas de localização das plantas industriais das ETNs. O processo de fragementação produtiva e a consequente formação das CGV parecem ter exacerbado os padrões de especialização comercial de ambos os países. Em que pese os diferentes posicionamentos e graus de participação dos dois países nas CGV (Hermida, 2016), fato é que as respectivas inserções nessas cadeias não foram capazes de modificar seus padrões de exportação e de importação. Os setores tradicionalmente exportadores - baseados em recursos naturais (intensivos em capital) e nas maquilas (intensivos em trabalho) - reforçaram suas participações nas exportações totais e no saldo comercial. Por outro lado, os setores que envolvem um maior conteúdo tecnológico tornaram-se crescentemente deficitários.

O resultado da maior dependência em relação aos insumos importados seria uma crescente fragilização da estrutura produtiva. Essa fragilização estaria relacionada à perda de elos em várias cadeias produtivas, ocasionando, assim, uma diminuição da densidade na matriz de interrelações industriais ${ }^{7}$. Se imaginarmos essa matriz como uma rede de trocas entre $n$ setores, sendo os setores (vértices) articulados por arcos (fluxos de bens e serviços), a menor densidade pode ser entendida como o desaparecimento de vários desses arcos ou fluxos. Nessa analogia com a teoria dos grafos, quando uma economia torna-se mais complexa, no sentido de que todo setor necessita crescentemente de outros setores como fornecedores de insumos para produzir, a demanda intermediária cresce como proporção do produto total e a probabilidade de encontrar trajetórias ou caminhos colapsando em circuitos também cresce. Em outras palavras, a fragilização da estrutura produtiva está relacionada com um menor nível de interdependência entre os setores.

Como apontado por Romero, Dietzenbacher e Hewings (2009), diante dos impactos da fragmentação espacial da produção, é necessário levar em consideração dois casos. No primeiro, algumas áreas (regiões ou países) podem perder determinadas etapas, tarefas, atividades ou elos que compõem o processo produtivo, enquanto outras são capazes de atraí-las. Do ponto de vista dos países que perdem essas etapas, a fragmentação poderia provocar uma diminuição na complexidade de seus sistemas produtivos, uma vez que algumas ou vários encadeamentos internos foram realocadas para outros países. As consequências de tal fragmentação em países com níveis relativamente avançados de industrialização poderia ser significativa, eventualmente provocando um processo de "esvaziamento" (hollowing out) (Hewings et al., 1998; Guo et al., 2005). Como resultado da fragmentação, esses países tornam-se mais dependentes em relação aos insumos importados do resto do mundo.

\footnotetext{
${ }^{7} \mathrm{O}$ processo de perda de complexidade estrutural também é referido como fragilização da estrutura produtiva, perda de densidade da estrutura produtiva, desindustrialização, entre outros. Nesse estudo, utilizaremos o termo complexidade estrutural.
} 
Em contraste, do ponto de vista dos países que estão recebendo essas etapas produtivas, a fragmentação produtiva poderia aumentar a complexidade estrutural. Contudo, seria necessário que adicionalmente à fragmentação - fosse criados alguns encadeamentos entre as empresas recentemente instaladas, em geral ETNs, e as empresas nacionais. Em um caso extremo do que poderíamos chamar de "setores de enclave", quando a demanda intermediária das novas empresas é dirigida aos insumos importados, gerando poucos encadeamentos com a economia doméstica, então a hipótese de que fragmentação poderia aumentar a complexidade estrutural pode não se verificar. Esses setores de enclave operam em países em desenvolvimento com o objetivo de desenvolver fases específicas dos processos produtivos apresentando alta intensidade tecnológica. Os insumos intermediários requeridos são comprados externamente e o produto é utilizado em subsequentes atividades manufatureiras em plantas localizadas em outros países.

\section{A inserção nas cadeias globais de valor e a evolução da complexidade estrutural do Brasil e do México entre 1995 e 2011}

O Brasil e o México atravessaram dois distintos processos de abertura comercial, que afetaram de maneira diferenciada as suas respectivas estruturas produtivas ${ }^{8}$. Embora difiram em suas intensidades e padrões, ambos os processos aumentaram progressivamente a dependência em relação aos insumos importados. Para autores como Britto (2002), Kupfer (2005) e Fraga-Castillo e MorenoBrid (2016), esse aumento está relacionado aos novos investimentos em modernização, aquisição e ampliação da capacidade instalada. A inserção dos países nas CGV tendeu a reforçar essa maior dependência em relação às importações.

Ao longo da década de 1990 foi se definindo o tipo de configuração e inserção comercial dos países da América Latina, principalmente Brasil e México, em um contexto de crescente dispersão geográfica da produção. Uma primeira característica é que o México aplicou medidas mais amplas e aceleradas em seu processo de liberalização econômica do que o Brasil. Isso não só porque foram iniciadas desde 1986 - o ingresso do México no Acordo Geral de Tarifas e Comércio (GATT na sigla em inglês) -, mas também pela rapidez e intensidade na redução das tarifas, assim como nas medidas de proteção não-tarifárias, tendência reforçada com a assinatura do TLCAN, em 1994.

Essas diferentes velocidades e perfis de abertura comercial alçaram o México a uma das economias com maior grau de abertura, medida pela relação $\left(\frac{X+M}{P I B}\right)$, do mundo. O gráfico 1 mostra como o país, já em 1990, apresentava o maior grau de abertura entre os países selecionados, apresentando quedas apenas em períodos de crise mundial (em 1994, com o chamado "efeito tequila", e em 2001, com a crise desencadeada pelos ataques terroristas). O grau de abertura do México é superior a todos os países da América Latina (AL) e também em relação aos países da OCDE, apresentando um rápido crescimento depois da assinatura do TLCAN. Contudo, como observado por Fraga-Castillo e Moreno-Brid (2016), essa maior abertura comercial da economia mexicana não resultou em maiores taxas de crescimento econômico. Um dos motivos elencados pelos autores é que a taxa de crescimento das importações mexicanas tendeu a apresentar taxas de crescimento sistematicamente maiores do que as taxas de crescimento das exportações, o que não ocorreu com a economia brasileira. O resultado seria pressões sobre o balanço de pagamentos da economia mexicana.

\footnotetext{
${ }^{8}$ O México inicia o seu processo de abertura comercial unilateral logo depois da crise da dívida externa em 1982 (Ros, 2015), enquanto o Brasil adota suas primeira medidas tendentes a uma maior abertura comercial no final da década de 1980 (Carneiro, 2002). A assinatura de acordos regionais, como o Mercosul e o TLCAN, visavam precisamente não apenas uma maior integração com seus parceiros regionais, mas também foram medidas adotadas com o objetivo de utilizar as filiais das ETNs como plataformas exportadoras à esses mercados.
} 


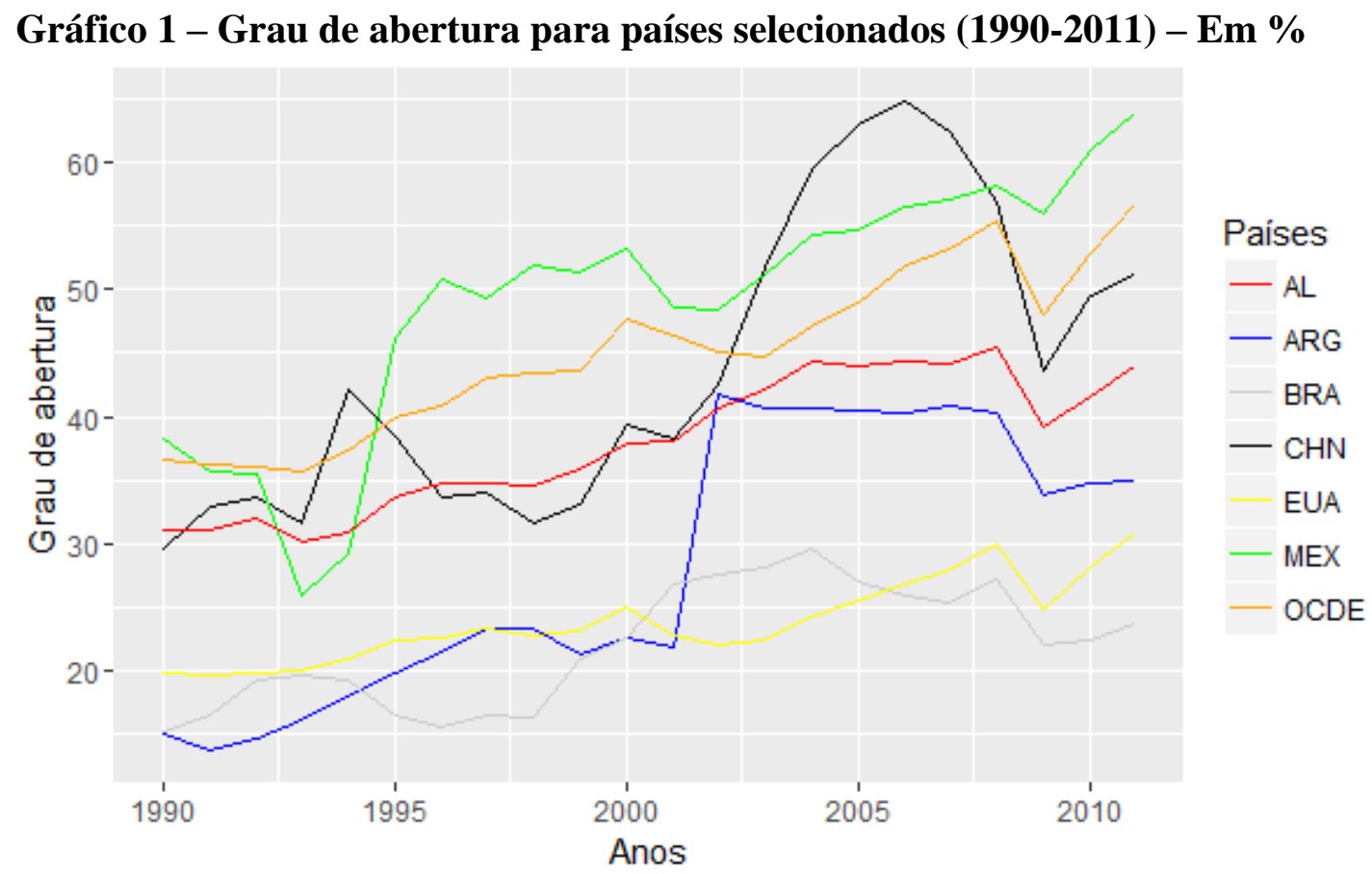

Fonte: elaboração própria a partir de dados da CepalStat.

Outra importante característica presente no período pós-abertura comercial e de inserção nas CGV diz respeito a forte relação positiva entre a taxa de crescimento do Produto Interno Bruto (PIB) e a taxa de crescimento das importações. No caso do Brasil, o período de 2004 a 2010, denominado como "boom das commodities" (Marconi, 2015), foi caracterizado por um crescimento vertiginoso das importações. Como podemos observar no gráfico 2, houve uma grande concentração dos pontos exatamente entre 2004-2010. Um dos fatores apontados foi a persistente valorização da taxa real de câmbio a partir de 2003, como parte da política macroeconômmica de controlar a inflação e elevar o salário real dos trabalhadores.

É possível perceber como o processo de abertura comercial, iniciada no final da década de 1980 e aprofundada ao longo da década de 1990, tendeu a criar uma dependência estrutural da economia brasileira em relação às importações. O caráter estrutural advém do fato de que os circuitos de demanda intermediária dos setores nacionais tendem a ser fechados crescentemente por insumos importados nos ciclos expansivos da economia brasileira. O resultado dessa maior dependência seria uma maior fragilização da estrutura produtiva no sentido de que os efeitos de encadeamentos entre os setores tenderiam a diminuir? .

\footnotetext{
${ }^{9}$ Para Hirschman (1961) e Leontief (1985), o processo de desenvolvimento econômico poderia ser visto como o preenchimento das células vazias de uma matriz de insumo-produto ou como a montagem de um quebra-cabeças. Em um ambiente de processos produtivos fragmentados, a característica marcante para alguns países é, porém, um desandensamento das interrelações setoriais.
} 


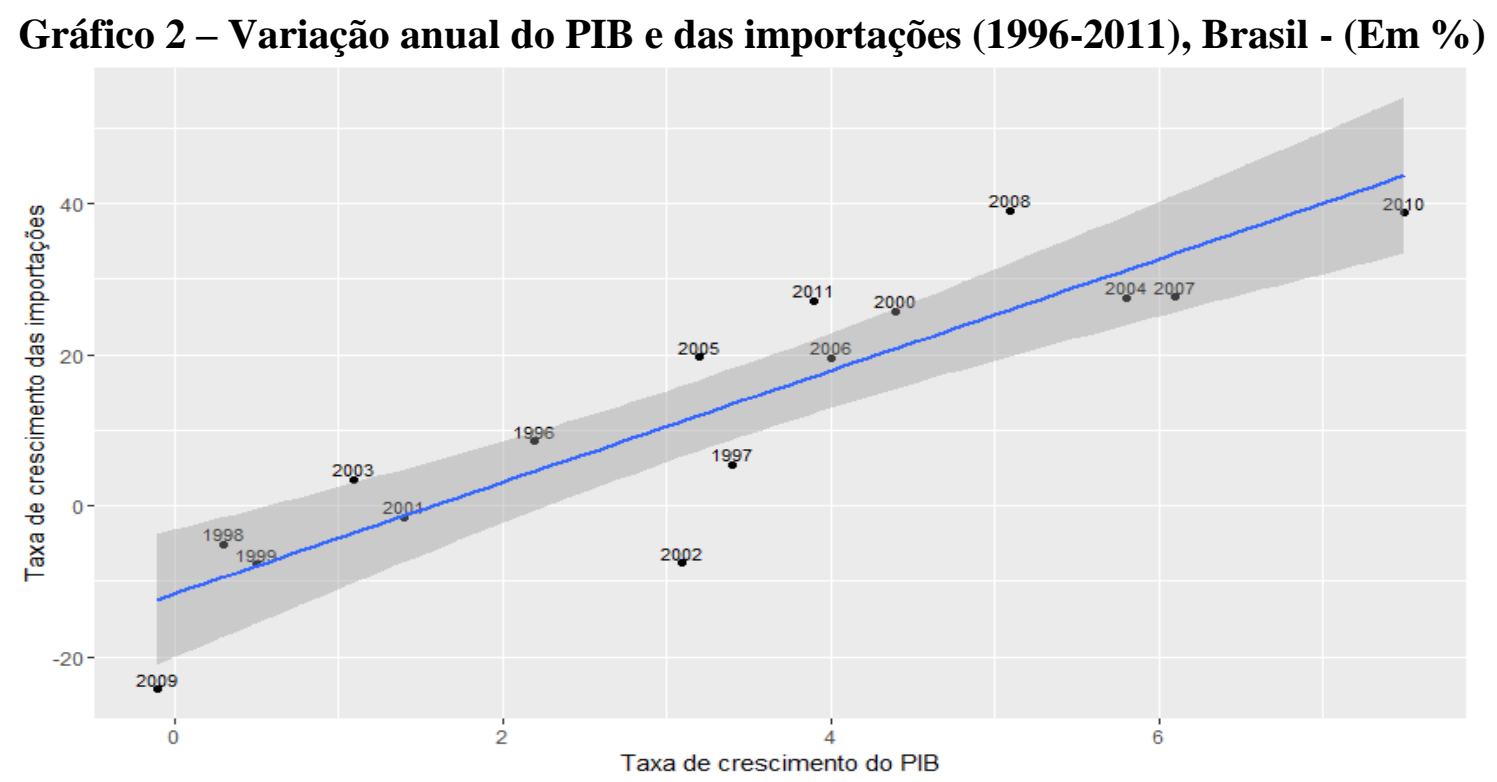

Fonte: elaboração própria a partir de dados da WIOD e da CEPALStat.

O caso do México revela um padrão bastante similar ao brasileiro, mostrando uma forte relação entre a taxa de crescimento do PIB e a das importações (gráfico 3). Contudo, diferentemente do padrão brasileiro, os pontos estão mais dispersos ao longo do tempo. A assinatura do TLCAN, em 1994, juntamente com a valorização da taxa real de câmbio em 1995 (López, 1998), teve o efeito conjunto de aprofundar uma dependência historicamente estabelecida em relação às importações, principalmente aquelas provenientes dos Estados Unidos. Para autores como López (1998) e Ros (2015), o baixo crescimento da economia mexicana no período está relacionado ao aumento no coeficiente de importações. Esse aumento teria como resultado que os impulsos advindos da demanda interna teriam sido filtrados do mercado interno, disminuindo o multiplicador do gasto autônomo ${ }^{10}$.

Como apontado por Moreno-Brid e Ros (2010), em termos de comércio exterior o México apareceu como um dos países de maior expansão na região e no mundo, particularmente na década de 1990. Este crescimento foi observado nas exportações, mas também se foi o peso dos componentes e insumos importados, que cresceram em ritmo mais acelerado do que as exportações. Como resultado o país apresentou, por um lado, superávits comerciais com os países do TLCAN, mas crescentes déficits com os demais países, principalmente os asiáticos. O efeito final foi o aparecimento de déficits persistentes em transações correntes e pressões adicionais sobre o balanço de pagamentos (Moreno-Brid e Ros, 2010).

\footnotetext{
${ }^{10} \mathrm{O}$ gasto autônomo é a parte da demanda de bens e serviços que não depende da produção.
} 


\section{Gráfico 3 - Variação anual do PIB e das importações (1996-2011), México - (Em \%)}

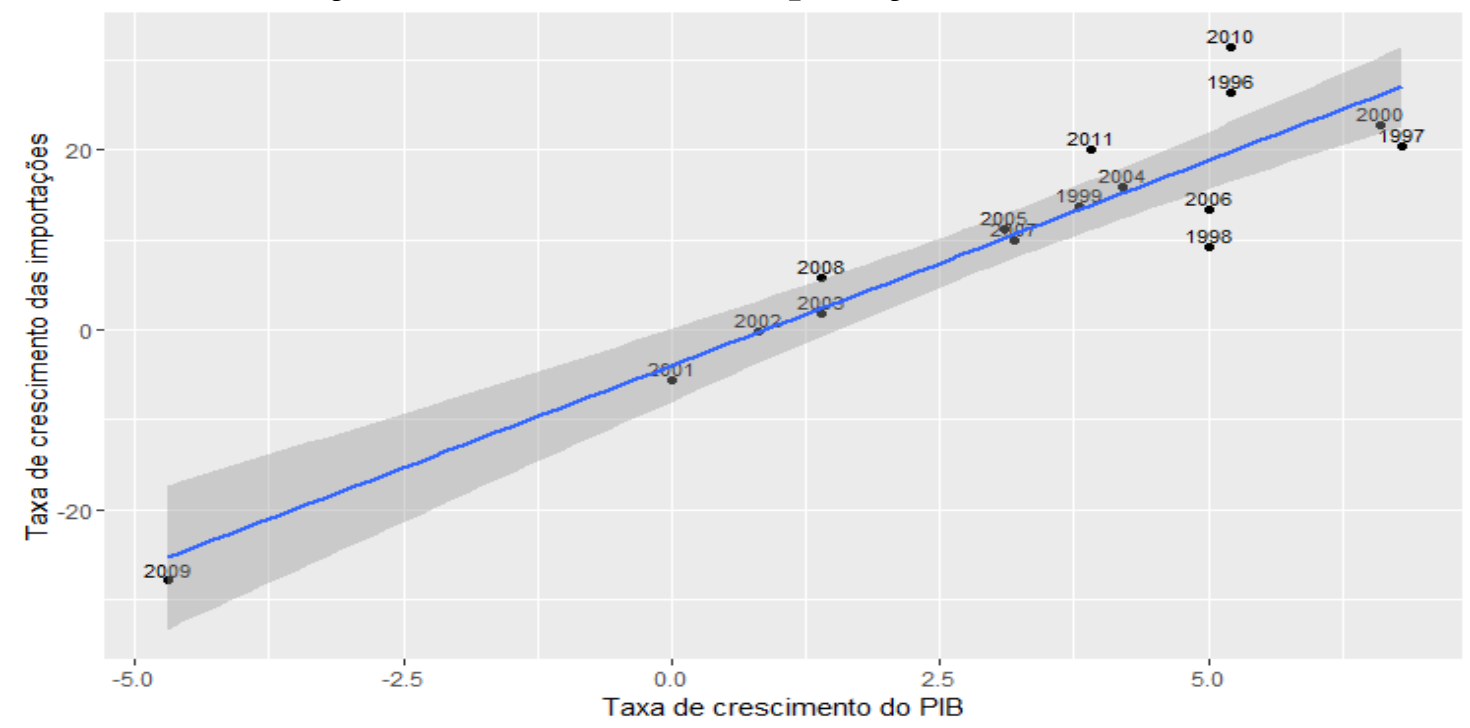

Fonte: elaboração própria a partir de dados da WIOD e da CEPALStat.

A análise das pautas de exportação e de importação do Brasil revela que, enquanto pelo lado das importações ocorreu uma maior diversificação, pelo lado das exportações o país apresentou uma crescente concentração em um pequeno grupo de setores. Uma forma sintética de analisar as evoluções de ambas as pautas é através do cálculo da contribuição na variação das importações/exportações totais por setor $^{11}$. A tabela 1 revela que aproximadamente $45 \%$ da contribuição na variação das exportações esteve concentrada em apenas três setores: comidas, bebidas e fumo (18\%), extração vegetal (15\%) e agricultura, caça, silvicultura e pesca (12\%). Pelo lado das importações, há uma maior dispersão nas contribuições setoriais, indicando que a penetração das importações ocorreu de forma mais generalizada na economia brasileira desde o processo de abertura comercial em 1994 e ao longo do processo de integração às CGV nos anos 2000 .

É interessante notar que mesmo nos setores da agropecuária e da construção, cujas cadeias produtivas são verticalmente integradas, observou-se uma maior penetração das importações. Outro fato que chama a atenção é a presença de sete setores como os principais contribuidores tanto na variação das importações, quanto das exportações. Por um lado, esses resultados apontam no sentido de uma maior presença do comércio intra-setorial, mas, por outro lado, mostra a existência de desequilíbrios nas balanças comerciais em determinados setores, como equipamentos de transporte, coque e petróleo refinado e químicos e produtos químicos.

\footnotetext{
${ }^{11}$ De acordo com Britto (2002), é possível calcular a contribuição setorial da seguinte forma: $\frac{\left(m_{2011}^{i}-m_{1995}^{i}\right)}{\left(m_{2011}^{t}-m_{1995}^{t}\right)} * 100$.
} 
Tabela 1 - As 10 principais contribuições na variação das importações e exportações totais entre 1995-2011 - Brasil (em \%)

\begin{tabular}{lr|lcr}
\hline \multicolumn{1}{c|}{ Importações } & \multicolumn{2}{c}{ Exportações } \\
\hline Equipamentos de transporte & 9 & Comidas, bebidas e fumo & 18 \\
Coque, petróleo refinado e combustível nuclear & 8 & Extração vegetal & 15 \\
Químicos e produtos químicos & 7 & Agricultura, caça, silvicultura e pesca & 12 \\
Extração vegetal & 6 & Equipamentos de transporte & 8 \\
Equipamentos elétricos e ópticos & 6 & Metais básicos e metais fabricados & 7 \\
Agricultura, caça, silvicultura e pesca & 6 & Químicos e produtos químicos & 5 \\
Construção & 5 & Coque, petróleo refinado e combustível nuclear & 4 \\
Metais básicos e metais fabricados & 5 & Hotéis e restaurantes & 3 \\
Comidas, bebidas e fumo & 4 & Celulose, papel, impressão e publicação & 2 \\
Maquinaria não especificadas & 3 & Transporte terrestre & 2 \\
\hline
\end{tabular}

Fonte: elaboração própria a partir de dados da WIOD.

Do ponto de vista da economia mexicana, é possível perceber como há uma maior concentração das contribuições tanto do lado das exportações, quanto do lado das importações. As maiores contribuições na variação das exportações ocorrem nos setores equipamentos elétricos e ópticos (21\%), equipamentos de transporte (14\%) e construção (9\%), enquanto as maiores contribuições do lado das importações também estão nos setores de equipamentos de transporte (25\%), equipamentos elétricos e ópticos $(21 \%)$ e extração vegetal $(18 \%)$. Esses resultados mostram que, contrariamente ao caso brasileiro, o padrão de comércio exterior mexicano é fortemente complementar no sentido de que o padrão de comércio exterior depende das exportações e das importações dos mesmos setores.

Tabela 2 - As 10 principais contribuições na variação das importações e exportações totais entre 1995-2011 - México (em \%)

\begin{tabular}{lr|ll}
\hline \multicolumn{1}{c|}{ Importações } & \multicolumn{2}{c}{ Exportações } \\
\hline Equipamentos elétricos e ópticos & 21 & Equipamentos de transporte \\
Equipamentos de transporte & 14 & Equipamentos elétricos e ópticos & 25 \\
Construção & 9 & Extração vegetal & 21 \\
Metais básicos e metais fabricados & 7 & Maquinaria não especificadas & 18 \\
Transporte terrestre & 4 & Comidas, bebidas e fumo & 3 \\
Eletricidade, gás e água & 4 & Comércio por atacado & 3 \\
Agricultura, caça, silvicultura e pesca & 3 & Químicos e produtos químicos & 3 \\
Extração vegetal & 3 & Comércio a varejo & 3 \\
Venda, manutenção e reparação de veículos automóveis & 3 & Outras manufaturas & 2 \\
Comércio a varejo & 2 & Coque, petróleo refinado e combustível nuclear & 2 \\
\hline
\end{tabular}

Fonte: elaboração própria a partir de dados da WIOD.

Os resultados acerca dos padrões de comércio exterior do Brasil e do México mostram como os dois países adotaram diferentes estratégias de inserção externa ao longo da década de 1990 e nos anos 2000. Como apontado por Katz (2000), esses diferentes padrões de inserção externa dos dois países surgem já na década de 1980, quando ambos os países abandonam a industrialização por 
substituição de importações e adotam diferentes estratégias de desenvolvimento ${ }^{12}$, com ênfase na abertura comercial por meio de reduções tarifárias e não-tarifárias (Ros, 1994; Kume, 1996).

As reestruturações industriais que se seguiram às aberturas comerciais do Brasil e do México, entre as décadas de 1980 e 1990, introduziram um forte componente estrutural nas importações, reforçando padrões de especialização comercial e de estrutura produtiva constituídos no período de industrialização por substituição de importações (Coutinho, 1997; Ros, 2015). Como apontado por Coutinho (1997), Britto (2002) e Moreno-Brid e Ros (2010), esse caráter estrutural das importações de insumos intermediários estaria relacionado à uma crescente fragilização das estruturas produtivas. De acordo com esses autores, a fragilização assumiu formas variadas, como a redução do valor agregado das cadeias industriais, a substituição da oferta doméstica por fornecedores estrangeiros e a substituição da produção nacional por insumos importados.

A maior dependência das economias brasileira e mexicana em relação aos insumos intermediários importados é uma das principais características da inserção dos países desenvolvidos e periféricos nas CGV. Isso decorre do processo de fragmentação dos processos produtivos, liderado pelas ETNs, que localizam as várias etapas e tarefas da produção de acordo com os custos da mãode-obra de cada país (Medeiros, 2010). As tabelas 3 e 4 mostram os 10 principais insumos intermediários importados e exportados pelo Brasil e pelo México entre 1994 e $2014^{13}$.

Do ponto de vista da economia brasileira, percebe-se um crescimento dos insumos intermediários que são simultaneamente exportados e importados. Em 1994, apenas dois insumos intermediários foram simultaneamente exportados e importados, 78433 e 78439, inlcuídos na categoria de partes e acessórios para automóveis. Já em 2014, 7 dos 10 insumos intermediários foram simultaneamente exportados e importados: 71491, 78439, 7478, 79295, 78432, 78434 e 78435 . Os dados mostram que o comércio exterior de insumos intermediários do Brasil tem um forte peso de partes e peças para automóveis, máquinas e equipamentos para a geração de energia e máquinas industriais gerais. É interessante notar que a categoria de aparelhos e equipamentos eletrônicos apresenta uma significativa participação pelo das importações, mas não pelo lado das exportações, revelando que o Brasil é um importador para essa categoria de insumos.

Entre os 7 insumos intermediários que foram simultaneamente exportados e importados, em 2014, 4 pertencem à categória de partes e acessórios para automóveis. São eles: outras peças e acessórios de carroçarias (78432), caixa de marchas (78434), eixos motores (78435) e outras partes e acessórios (78439). Esse padrão de comércio exterior dos insumos intermediários revela, por um lado, a existência de um importante componente de comércio intra-industrial, e, por outro lado, a inserção do Brasil nas etapas mais dinâmicas das CGV ocorreu preponderantemente por meio da categoria de partes e acessórios para automóveis ${ }^{14}$. Como apontado por Castilho e Souza (2016), uma parcela significativa desse comércio ocorre dentro dos países pertencentes ao Mercado Comum do Sul (Mercosul) e com os Estados Unidos.

\footnotetext{
12 Segundo Haggard (1992), uma estratégia de desenvolvimento pode ser definida como um conjunto de políticas econômicas elaboradas com um propósito. Tais estratégias emergem como um resultado das condições políticas e econômicas existentes no país e refletem particulares condições sociais e políticas prevalecentes no momento da formulação das políticas.

${ }^{13}$ Como os dados das matrizes da WIOD estão agregados ao nível de 35 setores, não é possível investigar com maiores detalhes a evolução dos insumos intermediários exportados e importados pelo Brasil e pelo México. A forma encontrada para superar essa limitação foi utilizar o Standard International Trade Classification (SITC), Rev.3, especificamente as partes, peças e componentes incluídas nos capítulos 7 (Máquinas e equipamentos de transporte) e 8 (Manufaturas diversas) a 4 e 5 dígitos. Para ver a lista completa dos insumos intermediários, com os respectivos códigos SITC, ver Athukorala e Menon (2010).

${ }^{14}$ Também podemos incluir outras partes de aviões e helicópteros (79295). As exportações desses produtos são realizadas principalmente pela Embraer, que participa ativamente nas CGV .
} 
Tabela 3 - Os 10 principais insumos intermediários exportados e importados (em \% do total de insumos intermediários) - Brasil (1994 e 2014)

\begin{tabular}{|c|c|c|c|}
\hline SITC - Códigos & 1994 & SITC - Códigos & 2014 \\
\hline \multicolumn{4}{|c|}{ Exportação } \\
\hline 78439 - Partes e acessórios de automóveis & 16 & $\begin{array}{l}71491 \text { - Máquinas e equipamentos para produção de } \\
\text { energia }\end{array}$ & 15 \\
\hline 7611 - Aparel. e equip. de telecomunicações & 7 & 78439 - Partes e acessórios de automóveis & 11 \\
\hline $\begin{array}{l}71391 \text { - Máquinas e equipamentos para produção } \\
\text { de energia }\end{array}$ & 7 & 7478 - Máquinas industriais gerais & 5 \\
\hline $\begin{array}{l}71323 \text { - Máquinas e equipamentos para produção } \\
\text { de energia }\end{array}$ & 4 & 79295 - Outros equipamentos de transporte & 5 \\
\hline 78434 -Partes e acessórios de automóveis & 4 & $\begin{array}{l}71322 \text { - Máquinas e equipamentos para produção de } \\
\text { energia }\end{array}$ & 4 \\
\hline 78433 - Partes e acessórios de automóveis & 4 & $\begin{array}{l}71391 \text { - Máquinas e equipamentos para produção de } \\
\text { energia }\end{array}$ & 4 \\
\hline 78425 - Partes e acessórios de automóveis & 4 & 78432 - Outros equipamentos de transporte & 4 \\
\hline 78435 - Partes e acessórios de automóveis & 3 & $\begin{array}{l}71491 \text { - Máquinas e equipamentos para produção de } \\
\text { energia }\end{array}$ & 4 \\
\hline 79295 - Outros equipamentos de transporte & 3 & 78434 - Partes e acessórios de automóveis & 3 \\
\hline $\begin{array}{l}71481 \text { - Máquinas e equipamentos para produção } \\
\text { de energia }\end{array}$ & 2 & 78435 - Partes e acessórios de automóveis & 3 \\
\hline \multicolumn{4}{|c|}{ Importação } \\
\hline $\begin{array}{l}78434 \text { - Partes e acessórios de automóveis } \\
7128 \text { - Máquinas e equipamentos para produção de } \\
\text { energia }\end{array}$ & 7 & $\begin{array}{l}76493 \text { - Aparel. e equip. de telecomunicações } \\
78439 \text { - Partes e acessórios de automóveis }\end{array}$ & 9 \\
\hline $\begin{array}{l}78439 \text { - Partes e acessórios de automóveis } \\
77641 \text {-Máquinas, aparelhos e equipamentos } \\
\text { elétricos }\end{array}$ & 5 & $\begin{array}{l}75997 \text { - Máquinas de escritório e automáticas } \\
78434 \text { - Partes e acessórios de automóveis }\end{array}$ & 6 \\
\hline 76499 - Aparel. e equip. de telecomunicações & 4 & 71491 - Aparel. e equip. de telecomunicações & 5 \\
\hline 76493 - Aparel. e equip. de telecomunicações & 4 & 78432 - Partes e acessórios de automóveis & 4 \\
\hline $\begin{array}{l}75997 \text { - Máquinas de escritório e automáticas } \\
77258 \text {-Máquinas, aparelhos e equipamentos }\end{array}$ & 4 & 79295 - Outros equipamentos de transporte & 3 \\
\hline elétricos & 4 & 78435 - Partes e acessórios de automóveis & 2 \\
\hline $\begin{array}{l}77611 \text {-Máquinas, aparelhos e equipamentos } \\
\text { elétricos }\end{array}$ & 3 & 7478 - Máquinas industriais gerais & 2 \\
\hline $\begin{array}{l}77643 \text {-Máquinas, aparelhos e equipamentos } \\
\text { elétricos }\end{array}$ & 2 & 7484 - Máquinas industriais gerais & 2 \\
\hline
\end{tabular}

Fonte: elaboração própria a partir de dados da Comtrade.

A análise do saldo comercial em bens intermediários revela um crescimento nos déficits comerciais entre 1994 e 2014. Como podemos observar no gráfico 4, em 1994 o déficit, em milhões de (US\$) dólares correntes, foi de aproximadamente US\$2.500 milhões, enquanto que em 2014 atingiu mais de US\$ 24.000 milhões. Esses resultados revelam uma baixa competitividade da produção nacional em relação aos insumos importados desde a consolidação do processo de abertura comercial, em 1994, até uma maior integração nas CGV durante a primeira década do século XXI. Então, esse padrão de especialização comercial dos bens intermediários centrado na categoria de partes e acessórios para automóveis mostrou um comportamento pressionou ainda mais os déficits na balança comercial do setor de bens manufaturados (Marconi, 2015). 


\section{Gráfico 4 - Saldo comercial em bens intermediários (em US\$ correntes), Brasil (1994- 2014)}

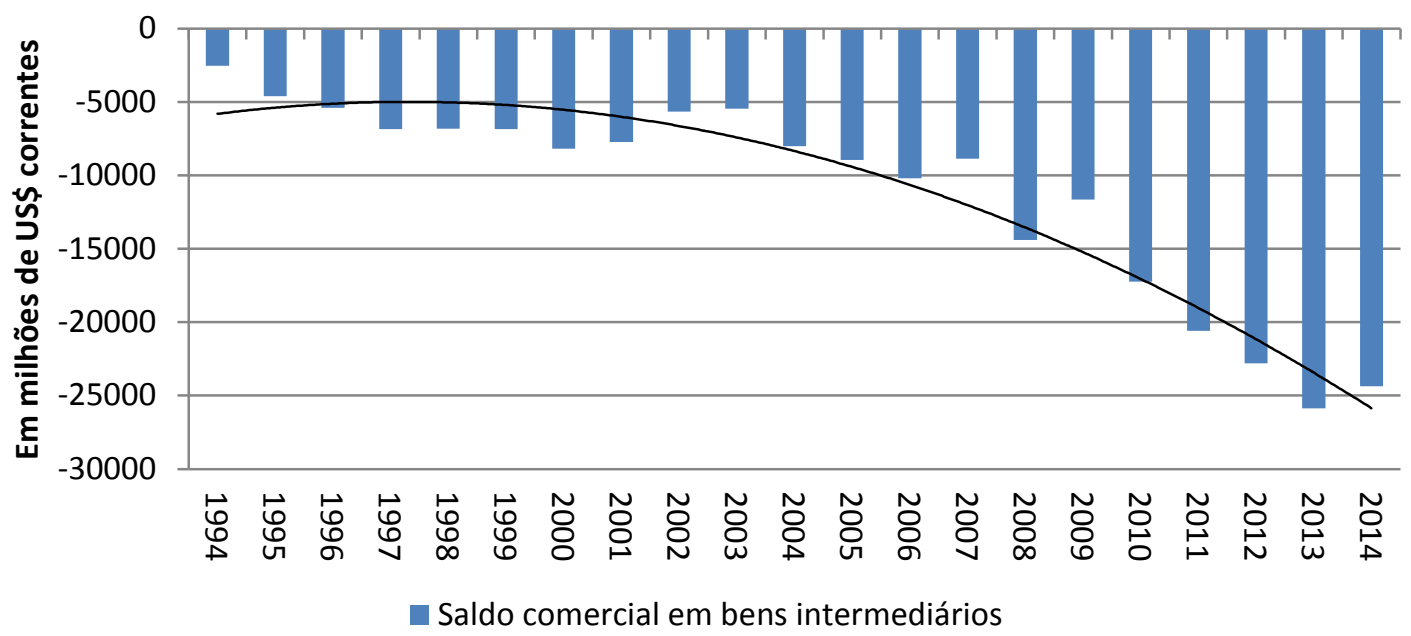

Fonte: elaboração própria a partir de dados da Comtrade.

A tabela 4 apresenta os dados para as exportações e importações de insumos intermediários da economia mexicana entre 1996 e $2014^{15}$. O fluxo total de comércio (exportações mais importações) em bens intermediários pela economia mexicana é superior àquele verificado para a economia brasileira: em 2014, o fluxo de comércio do México para esse tipo de bem foi de mais de US\$ 160 milhões e o do Brasil foi de pouco mais de US\$ 46 milhões. Isso significa que o fluxo comercial em insumos intermediários realizado pela economia mexicana é mais de três vezes superior ao do Brasil. Vale lembrar, que os insumos intermediários são as partes, peças e acessórios incluídos nos capítulos 7 e 8 do Standard International Trade Classification, tendo em vista que as maiores taxas de crescimento em insumos intermediários foram verificadas nesses dois itens (Athukorala e Menon, 2010).

A tabela 4 revela ainda que tanto as exportações, quanto as exportações de insumos intermediários realizadas pelo México são mais concentradas em um menor número de produtos do que no caso da economia brasileira. Pelo lado das exportações, verificou-se o maior peso dos aparelhos e equipamentos de telecomunicações (7611), com uma participação no total exportado de insumos intermediários de $21 \%$. Já as exportações de máquinas e equipamentos para produção de energia reduziram sua participação em 10\% entre 1996 e 2014. A cetegoria de bens que mais ganhou participação nesse período foi a de partes e peças de automóveis, cuja participações era de $5 \%$, em 1996, com base nas exportações de outras partes e acessórios (78439). Em 2014, as exportações de partes e peças para automóveis representaram 15\%, dados os aumentos nas participações das exportações de outras partes e peças de carrocerias (78432), freios e suas partes (78433), caixa de marchas (78434) e eixos motores (78435). O segmento de outras partes e acessórios de veículos apresentou uma participação de $12 \%$, em 2013, o que indica uma forte que em suas exportações para o ano de 2014. Assim, diferentemente do caso brasileiro que apresentou uma perda de participação no segmento de peças e acessórios para veículos, o comércio exterior mexicano em insumos intermediários passou a depender cada vez mais da dinâmica desses cinco produtos.

\footnotetext{
${ }^{15}$ Iniciamos a análise do comércio exterior em bens intermediários da economia mexicana em 1996 porque 1994 e 1995 são anos de crise no balanço de pagamentos da economia, o que distorcionaria a análise do comércio exterior. Essa crise ficou conhecida como "efeito tequila" (Ibarra e Moreno-Brid, 2001).
} 
Tabela 4 - Os 10 principais insumos intermediários exportados e importados (em \% do total de insumos intermediários) - México (1994 e 2014)

\begin{tabular}{|c|c|c|c|}
\hline SITC - Códigos & 1996 & SITC - Códigos & 2014 \\
\hline \multicolumn{4}{|c|}{ Exportação } \\
\hline 7611 - Aparel. e equip. de telecomunicações & $21 \%$ & 7611 - Aparel. e equip. de telecomunicações & $21 \%$ \\
\hline 71322 - Máq. e equip. para produção de energia & $14 \%$ & $\begin{array}{l}77313 \text { - Máquinas, aparelhos e equipamentos } \\
\text { elétricos }\end{array}$ & $9 \%$ \\
\hline 76493 - Aparel. e equip. de telecomunicações & $9 \%$ & 82119 - Móveis e suas partes & $7 \%$ \\
\hline $\begin{array}{l}77641 \text { - Máquinas, aparelhos e equipamentos } \\
\text { elétricos }\end{array}$ & $6 \%$ & 78432 - Partes e acessórios de automóveis & $6 \%$ \\
\hline 78439 - Partes e acessórios de automóveis & $5 \%$ & $\begin{array}{l}77261 \text { - Máquinas, aparelhos e equipamentos } \\
\text { elétricos }\end{array}$ & $5 \%$ \\
\hline $\begin{array}{l}77259 \text { - Máquinas, aparelhos e equipamentos } \\
\text { elétricos }\end{array}$ & $4 \%$ & 71322 - Máq. e equip. para produção de energia & $4 \%$ \\
\hline $\begin{array}{l}77255 \text { - Máquinas, aparelhos e equipamentos } \\
\text { elétricos }\end{array}$ & $3 \%$ & 78435 - Partes e acessórios de automóveis & $4 \%$ \\
\hline 74159 - Máquinas industriais gerais & $3 \%$ & 71391 - Máq. e equip. para produção de energia & $4 \%$ \\
\hline $\begin{array}{l}77812 \text {-Máquinas, aparelhos e equipamentos } \\
\text { elétricos }\end{array}$ & $2 \%$ & 78434 - Partes e acessórios de automóveis & $3 \%$ \\
\hline 71392 - Máq. e equip. para produção de energia & $2 \%$ & 78433 - Partes e acessórios de automóveis & $2 \%$ \\
\hline
\end{tabular}

71392 - Máq. e equip. para produção de energia

\section{Importação}

78432 - Partes e acessórios de automóveis

77611 - Máquinas, aparelhos e equipamentos elétricos

77645 - Máquinas, aparelhos e equipamentos elétricos

77259 - Máquinas, aparelhos e equipamentos elétricos

7722 - Máquinas, aparelhos e equipamentos elétricos

77643 - Máquinas, aparelhos e equipamentos elétricos

71391 - Máq. e equip. para produção de energia

76493 - Aparel. e equip. de telecomunicações

75997 - Máquinas de escritório e automáticas

78435 - Partes e acessórios de automóveis

\begin{tabular}{|l|l|r|}
\hline $8 \%$ & 78439 - Partes e acessórios de automóveis & $11 \%$ \\
\hline $8 \%$ & 75997 - Máquinas de escritório e automáticas & $7 \%$ \\
\hline $7 \%$ & 78432 - Partes e acessórios de automóveis & $6 \%$ \\
\hline $5 \%$ & 71323 - Máq. e equip. para produção de energia & $5 \%$ \\
\hline $5 \%$ & 78434 - Partes e acessórios de automóveis & $5 \%$ \\
\hline $4 \%$ & $\begin{array}{l}77282 \text { - Máquinas, aparelhos e equipamentos } \\
\text { elétricos }\end{array}$ & $4 \%$ \\
\hline $4 \%$ & $\begin{array}{l}77259 \text { - Máquinas, aparelhos e equipamentos } \\
\text { elétricos } \\
7 \%\end{array}$ & $\begin{array}{l}7611 \text { - Aparel. e equip. de telecomunicações } \\
71391 \text { - Máq. e equip. para produção de energia }\end{array}$ \\
\hline $3 \%$ & $\begin{array}{l}7139 \\
78435\end{array}$ & $3 \%$ \\
$3 \%$ & Partes e acessórios de automóveis & $3 \%$ \\
\hline
\end{tabular}

Fonte: elaboração própria a partir de dados da Comtrade.

A opção por um processo brusco de desregulações e a acelerada eliminação das barreiras tarifárias e não-tarifárias ao comércio, como foi característico da estratégia de desenvolvimento econômico adotado pelo México na década de 1980, provocou uma alteração abrupta em seu padrão de comércio. Esse novo padrão de comércio exterior baseado nas exportações e importações de insumos de partes, peças e componentes do setores de equipamentos de transporte e de equipamentos elétricos e ópticos acelerou o ritmo dos déficits comerciais do país ao longo da década de 1990. Outra característica preocupante desse padrão de comércio exterior é o aumento no conteúdo importado de insumos intermediários presente nas exportações mexicanas (Fujii e Cervantes, 2013), que tende a pressionar ainda mais o balanço de pagamentos da economia.

O gráfico 5 mostra como depois da assinatura do TLCAN, em 1994, o saldo comercial em bens intermediários da economia mexicana tendeu a se deteriorar. Conforme apontam Moreno-Brid e Ros (2010), a participação do México no TLCAN tendeu a gerar resultados aparentemente contraditórios sobre a balança comercial do país: por um lado, o México apresentou um crescente superávit comercial com seus parceiros comerciais do TLCAN, enquanto que, por outro lado, houve 
uma deterioração do saldo comercial com os países asiáticos, principalmente a China. O resultado global e setorial para os bens intermediários foi o aparecimento de díficits comerciais. A partir de meados dos anos 2000 esses déficits comerciais em bens intermediários foram parcialmente revertidos em função do aumento nos superávits comerciais do México com os Estados Unidos, que mais do que compensaram o crescimento dos déficits comerciais do México com a China.

\section{Gráfico 5 - Saldo comercial em bens intermediários (em US\$ correntes), México (1994- 2014)}

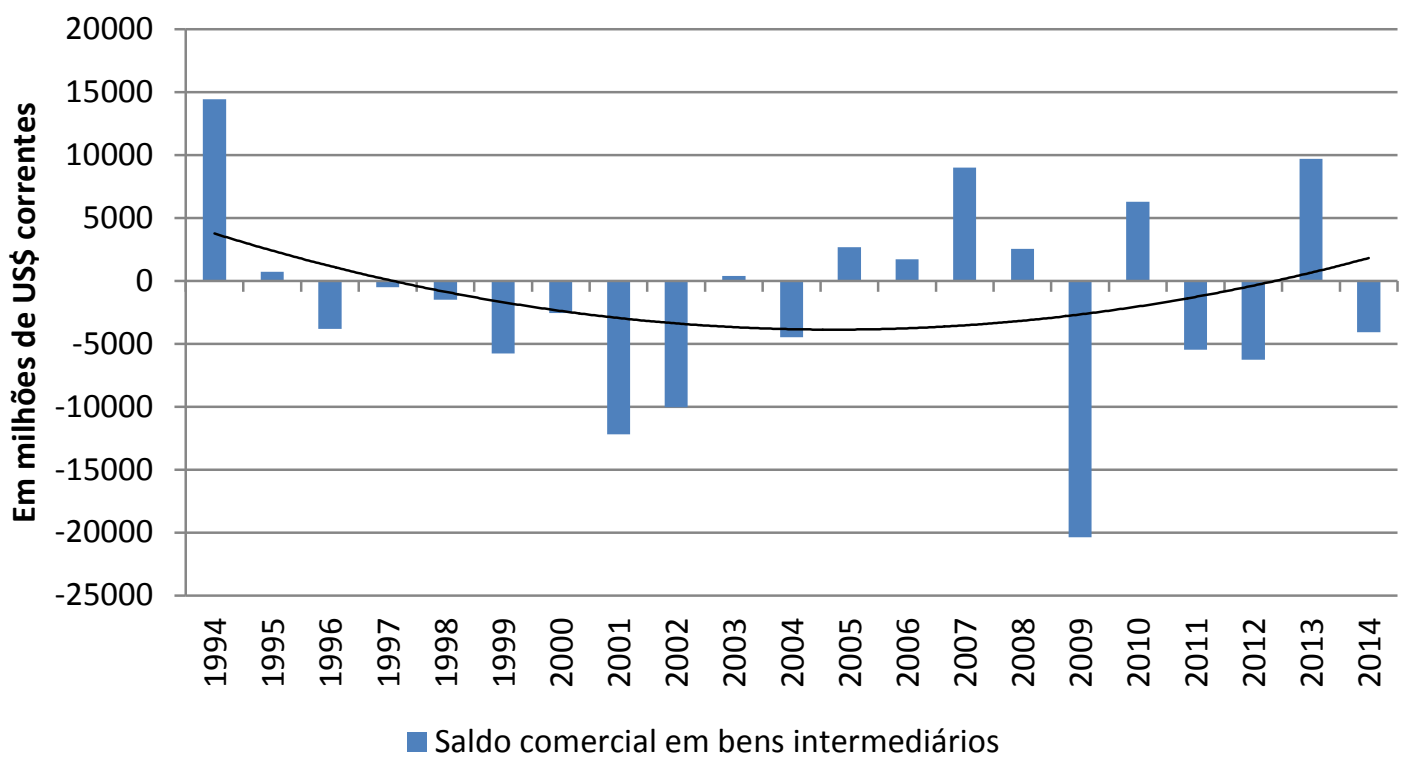

Fonte: elaboração própria a partir de dados da Comtrade.

É a partir desses diferentes padrões de comércio exterior que o Brasil e o México se inserem com níveis muito variados de participação nas CGV. Como apontado por Medeiros e Trebat (2017), esses diferentes padrões de inserção nas CGV dentro do conjunto de países periféricos mostram o caráter assimétrico dessa inserção. A assimetria está relacionada à crescente concentração e centralização do poder de comando sobre o valor criado nas CGV, de modo que países como Brasil e México participam em diferentes etapas dos processos produtivos. Essa assimetria é ainda mais relevante quando levamos em consideração a capacidade que os países periféricos têm em se apropriarem do valor criado dentro das CGV.

O caráter hierárquico da nova divisão internacional do trabalho gera uma acirrada concorrência nos estágios de produção com menores capacidades de gerar valor adicionado, como o processamento de matérias-primas (Brasil), que apresentam menores salários e menores margens de lucro para os trabalhadores e as empresas, respectivamente. No topo da hierarquia prevalece outro padrão de concorrência, centrado na capacidade de comandar os fluxos de bens e serviços e inovação, prevalecendo maiores salários e margens de lucros para trabalhadores e empresas (Medeiros e Trebat, 2017).

Como podemos observar na tabela $3^{16}$, no período entre 1995 e 2011 observou-se um aumento generalizado do conteúdo estrangeiro presente nas exportações brasileiras e mexicanas. No

\footnotetext{
${ }^{16}$ Um das principais características da fragmentação produtiva é o aumento do conteúdo importado presente nas exportações dos países. Essa é uma medida sintética para avaliar o grau de especialização vertical, que toma a seguinte forma (Dietzenbacher, 2013):
}

$$
E V=\frac{s^{\prime} M\left(I-A^{D}\right)^{-1} e}{s^{\prime} e}
$$


caso do Brasil, houve um aumento de $3 \%$ no valor adicionado contido nas exportações, que passou de 7,8\% para 10.8\%. Como apontam os estudos de Hermida (2016), Corrêa (2016) e Torracca e Castilho (2016), essa participação brasileira é relativamente pequena quando comparada aos países desenvolvidos e periféricos. Embora essa participação ainda apresente uma baixa participação do país nas CGV, é possível verificar um conjunto de setores que apresentaram um importante crescimento suas participações. Esses aumentos estiveram concentrados nos setores de fabricação de veículos automóveis (7.2\%), borracha e plásticos (6.7\%), máquinas e equipamentos elétricos (6.6\%), outros equipamentos de transporte (6.5\%) e equipamentos elétricos e ópticos (6.5\%). Como resultado, a participação do valor adicionado importado nas exportações manufatureiras nacionais subiu $4.2 \%$ entre 1995 e 2011.

Tabela 5 - Valor adicionado estrangeiro contido nas exportações do Brasil e do Mexico (em \% do total exportado) para os anos de 1995 e 2011

\begin{tabular}{|c|c|c|c|c|c|c|}
\hline \multicolumn{4}{|c|}{ Brasil } & \multicolumn{3}{|c|}{ México } \\
\hline Setores & 1995 & 2011 & $(\%)$ & 1995 & 2011 & $(\%)$ \\
\hline Total & 7.8 & 10.8 & 3.0 & 27.3 & 31.7 & 4.4 \\
\hline Agricultura, caça, silvicultura e pesca & 4.9 & 9.5 & 4.6 & 5.3 & 10.7 & 5.4 \\
\hline Indústrias extrativas e mineração & 10.1 & 9.9 & -0.2 & 3.3 & 4.3 & 1.0 \\
\hline Total das manufaturas & 10.1 & 14.3 & 4.2 & 38.6 & 43.5 & 4.9 \\
\hline Alimentos, bebidas, tabaco & 7.4 & 9.8 & 2.4 & 15.0 & 16.8 & 1.8 \\
\hline Têxteis e produtos têxteis & 6.0 & 8.9 & 2.9 & 31.6 & 37.5 & 5.9 \\
\hline Madeira e cortiça e suas obras & 5.2 & 9.2 & 4.0 & 10.1 & 18.2 & 8.0 \\
\hline Pasta de papel e cartão e seus artigos; edição e impressão & 7.8 & 9.6 & 1.8 & 21.9 & 31.6 & 9.7 \\
\hline Coque, produtos petrolíferos refinados e de combustível nuclear & 18.2 & 21.4 & 3.2 & 6.2 & 25.5 & 19.3 \\
\hline Borracha e Plásticos & 10.7 & 17.4 & 6.7 & 25.6 & 40.0 & 14.4 \\
\hline Outros produtos minerais não metálicos & 9.3 & 12.3 & 3.0 & 13.6 & 18.6 & 5.0 \\
\hline Metais básicos & 13.6 & 15.8 & 2.2 & 20.6 & 16.6 & -4.0 \\
\hline Fabricação de produtos metálicos & 9.7 & 13.1 & 3.4 & 41.0 & 45.8 & 4.8 \\
\hline Manufaturas Nec; recicláveis & 5.2 & 8.5 & 3.3 & 38.9 & 48.6 & 9.6 \\
\hline Máquinas e equipamentos, nec & 10.6 & 16.2 & 5.6 & 32.5 & 37.2 & 4.8 \\
\hline Produtos químicos & 11.4 & 15.8 & 4.5 & 14.8 & 26.3 & 11.5 \\
\hline Máquinas e aparelhos eléctricos n.e & 13.3 & 19.9 & 6.6 & 54.8 & 58.3 & 3.5 \\
\hline Fabricação de veículos automóveis, reboques e semireboque & 12.7 & 19.9 & 7.2 & 40.8 & 49.6 & 8.8 \\
\hline Outros Equipamentos de transporte & 12.0 & 18.5 & 6.5 & 24.5 & 33.2 & 8.7 \\
\hline Equipamentos elétricos e óticos & 17.6 & 24.1 & 6.5 & 62.0 & 64.1 & 2.1 \\
\hline Eletricidade, gás e água & 2.1 & 5.9 & 3.8 & 7.6 & 15.3 & 7.8 \\
\hline Construção & 6.3 & 8.9 & 2.6 & 11.3 & 11.3 & 0.0 \\
\hline Comércio atacado e varejo, reparos & 1.0 & 3.2 & 2.3 & 4.9 & 4.3 & -0.6 \\
\hline Hotéis e Restaurantes & 4.1 & 6.2 & 2.2 & 3.5 & 4.0 & 0.5 \\
\hline Transporte e estocagem & 6.0 & 10.0 & 4.1 & 5.6 & 8.6 & 3.0 \\
\hline $\begin{array}{l}\text { Serviços Postais e das Telecomunicações } \\
\text { Intermediação financeira }\end{array}$ & $\begin{array}{l}5.2 \\
1.9\end{array}$ & $\begin{array}{l}5.9 \\
3.3\end{array}$ & $\begin{array}{l}0.8 \\
1.4\end{array}$ & $\begin{array}{l}7.0 \\
2.2\end{array}$ & $\begin{array}{l}12.2 \\
3.5\end{array}$ & $\begin{array}{l}5.2 \\
1.3\end{array}$ \\
\hline Atividades imobiliárias & 0.5 & 0.7 & 0.3 & 1.4 & 1.0 & -0.4 \\
\hline Aluguel de Máquinas e equipamentos & 6.8 & 7.5 & 0.8 & 4.7 & 5.6 & 0.9 \\
\hline Computação e atividades relacionadas & 2.9 & 7.0 & 4.0 & 3.4 & 2.8 & -0.6 \\
\hline P\&D e outras atividades de negócio & 3.7 & 4.8 & 1.1 & 5.0 & 3.2 & -1.9 \\
\hline
\end{tabular}

Onde $s^{\prime}$ é um vetor diagonal unitário, $M$ é o vetor de importações, $\left(I-A^{D}\right)^{-1}$ é a inversa de Leontief com $A^{D}$ sendo a matriz de coeficientes de insumos domésticos e $e$ o vetor de exportações. A fórmula pode ser utilizada para uma análise agregada ou setorial. 
Administração pública e defesa; segurança social obrigatória

Educação

Saúde e Ação social

Outras atividades de serviços coletivos, sociais e pessoais

Fonte: elaboração própria a partir de dados da WIOD.

OBS: Nec: não especificadas.

A economia mexicana apresentou uma participação nas CGV quase três vezes superior relativamente à economia brasileira, passando de $27.3 \%$ para $31.7 \%$ entre 1995 e 2011. Já do ponto de vista das manufaturas, essa diferença é ainda maior, dado que, em 2011, o valor adicionado estrangeiro contido nas exportações manufatureiras mexicanas foi de $43.5 \%$, enquanto essa mesma participação para o Brasil foi de $14.3 \%$. Dentro do setor manufatureiro mexicano os maiores crescimentos ocorreram nos setores de coque, produtos petrolíferos refinados e de combustível nuclear $(19.3 \%)$, borracha e plásticos $(14.4 \%)$ e produtos químicos $(11.5 \%)$.

As estruturas produtivas dos dois países responderam de distintas formas a essas transformações advindas do comércio exterior. Contudo, o resultado comum a ambos os países foi o que se convencionou chamar de perda de densidade ou de complexidade no grau de articulação entre os setores (Coutinho, 1997; Britto, 2002; Marconi, 2015). Os estudos apontam que essa perda de complexidade está relacionada, em geral, pelo menor peso das manufaturas no valor adicionado (Marconi, 2015), pela redução no valor dos índices de encadeamentos para trás e para frente (Fornari e Gomes, 2015) ou pela perda de elos em várias partes das cadeias produtivas (Coutinho, 1997; Kupfer, 2005). A análise da complexidade a partir dos determinates das matrizes de insumo-produto possibilita uma leitura complementar a estes indicadores previamente $\operatorname{citados}^{17}$. O índice de complexidade estrutural elaborado a partir dos determinantes das matrizes de insumo-produto é um indicador sintético, que mostra toda a rede de interrelações diretas e indiretas presente em uma matriz. Lantner e Lebert $(2013,2015)$ calculam o índice de complexidade estrutural como ICE = $\frac{1-\Delta}{\Delta}$, onde $\Delta$ é o determinante da matriz de coeficientes técnicos.

Como podemos observar no gráfico 4, o índice de complexidade estrutural (ICE) diminuiu ao longo de todo o período em análise e a estrutura produtiva brasileira apresentou é mais complexa do que a mexicana. O ICE de complexidade estrutural da economia brasileira diminuiu 21.5 para 10.8 (variação negativa de -10.7), enquanto para a economia mexicana houve uma redução de 8.3 para 4.0 (veriação negativa de -4.4). É interessante mostrar que, embora as estratégias de inserção internacional de ambas as economias difiram em termos de intensidade e que ambos os países estejam localizados em diferentes etapas das $\mathrm{CGV}$, os dois países mostraram uma perda de complexidade em suas estruturas produtivas.

\footnotetext{
${ }^{17}$ Wong (1954) sugeriu que o determinante, $\Delta$, da matriz de coeficientes técnicos $(I-A)$ é uma medida relativa do volume da produção líquida e da complexidade do sistema de trocas. O determinante da matriz $(I-A)$ aparece como uma função da composição ou do arranjo interno da estrutura, isto é, da posição e da intensidade das ligações entre os setores que compõem a estrutura de trocas.
} 


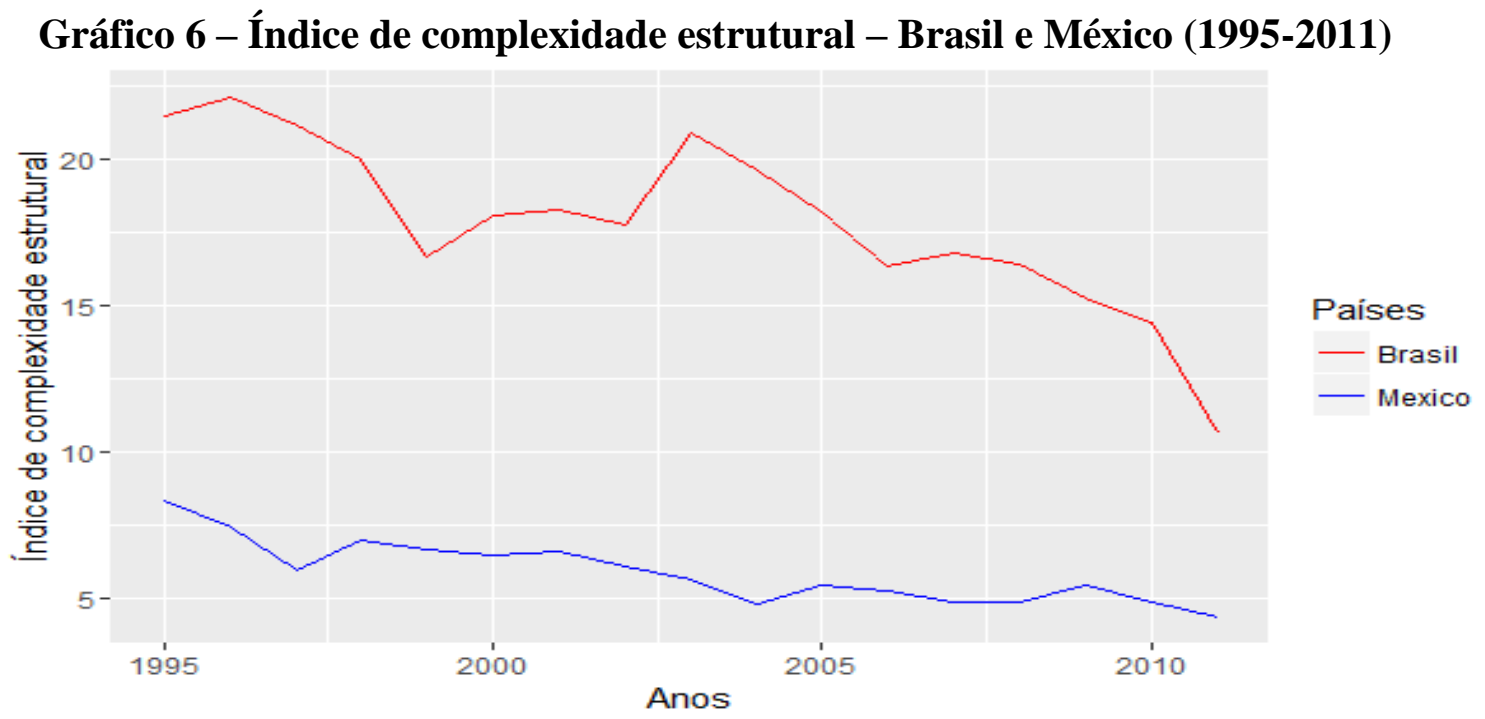

Fonte: elaboração própria a partir de dados da WIOD.

Entre os diferentes motivos apontados para essa perda de complexidade está a maior dependência da produção nacional em relação aos insumos intermediários importados. A maior dependência em relação aos insumos importados parece ter sido o resultado combinado de uma maior abertura comercial e dos comportamentos microeconômicos das empresas nacionais e transnacionais instaladas nos países. Estar mais integrado implicou em um aumento generalizado do conteúdo importado presente na articulação entre os setores. A inserção do Brasil e do México nas redes globais de produção e de valor ao longo dos anos 2000, ainda que em diferentes graus, parece ter reforçado os padrões de especialização comercial herdados da década anterior. Isso porque o Brasil e o México passaram a depender crescentemente de partes, peças e acessórios importados, o que, por sua vez, tendeu a enrigecer suas pautas exportadoras. O Brasil e o México necessitaram de maiores taxas de crescimento dos setores tradicionalmente exportadores, de modo a gerarem superávits comerciais, e, assim, conterem os déficits em transações correntes.

\section{Conclusões}

Neste artigo analisamos os efeito dos padrões de especialização comercial, em um ambiente de fragmentação produtiva, sobre as estruturas produtivas do Brasil e do México entre 1995 e 2011. A realização do estudo comparativo dessas duas economias se justifica por diversas razões, sendo as principais delas a similaridade do porte e da diversificação dos setores industriais dos dois países, além de serem as duas maiores economias da América Latina, o que confere a essas duas economias uma importante papel na dinâmica das demais economias da região. De um lado, o Brasil apresentou uma tendência à especialização nas exportações de produtos baseados em recursos naturais, enquanto que pelo lado das importações passou a depender cada vez mais dos insumos intermediários, principalmente de máquinas e equipamentos de transporte. Por outro lado, o México concentrou suas exportações nas maquilas manufatureiras de exportação, principalmente nos setores de máquinas e materias de transporte e equipamentos elétricos. As importações mexicanas estiveram concentradas em insumos intermediários para os setores de máquinas e equipamentos de transporte e equipamentos elétricos.

A inserção dos dois países nas cadeias globais de valor tendeu a aprofundar os padrões de comércio gestados durante a década de 1990. O Brasil tendeu a reforçar sua inserção nas cadeias de valor nas etapas upstream, ou seja, nas primeiras etapas dos processos de produção com a exportação de matérias-primas. Já o México, apresentou uma participação mais ativa e esteve localizado nas 
etapas mais dinâmicas das cadeias de valor, nas etapas downstream, quando o país processa insumos intermediários para posterior exportação.

O presente estudo também mostrou que um dos principais efeitos da maior dependência de ambos os países em relação aos insumos intermediários importados foi a perda de complexidade estrutural. O índice de complexidade estrutural, medido a partir dos determinantes das matrizes de insumo-produto e utilizando a teoria dos grafos de influência, é uma contribuição metodológica e empírica aos estudos de mudança estrutural e comércio exterior. Nesse sentido, o estudo contribui para uma melhor compreensão de como os setores se articulam e quais os efeitos que as exportações e importações têm no grau e padrão de interdependência entre os setores.

\section{Referências}

ATHUKORALA, P-C., MENON, J. Global Production Sharing, Trade Patterns, and Determinants of Trade Flows in East Asia. Working Papers on Regional Economic Integration 41, 2010.

BALDWIN, R. Trade and industrialization after globalization's $2^{\text {nd }}$ unbundling: how building and joining a supply chain are different and why it matters. NBER Working Paper, $\mathrm{n}^{\circ}$ 17716, 2011.

BODDIN, D. The role of newly industrialized economies in global value chains. IMF Working Paper, $\mathrm{n}^{\circ} 16,2016$.

BRITTO, G. Abertura comercial e reestruturação industrial no Brasil: um estudo dos coeficientes de comércio. 2002. 145 f. Dissertação (Mestrado em Economia) - Instituto de Economia, Universidade Estadual de Campinas, São Paulo.

CARNEIRO, R. Desenvolvimento em crise: a economia brasileira no pultimo quarto do século XX. São Paulo: Editora Unesp e UNICAMP, 2002.

CHENERY, H. Interaction between Industrialization and Exports. American Economic Association, 1980. World Bank Reprint Series n. 150, Washington, D.C.: World Bank.

CÔRREA, L. M. Trajetórias dos países em desenvolvimento nas cadeias globais de valor: upgrading, estágio produtivo e mudança estrutural. 2016. $173 \mathrm{f}$. Tese (Doutorado em Economia) - Instituto de Economia, Universidade Federal do Rio de Janeiro, Rio de Janeiro.

COUTINHO, L. A especialização regressiva: um balanço do desempenho industrial pós estabilização". In: VELLOSO, J.P.R. (Org.). Brasil: desafios de um país em transformação. Rio de Janeiro: José Olympio, 1997.

FORNARI, V. C., GOMES, R. Mudanças recentes nas relações intersetoriais: um exame das atividades de serviço e industriais a partir da análise de insumo-produto e de redes. Anais do XX Encontro Nacional de Economia Política, UNILA, 2015.

FORTER-McGREGOR, N., STEHRER, R. Value added content of trade: a comprehensive approach. Economics Letters, $n^{\circ} .120$, p. $354-357,2010$.

FRAGA-CASTILLO, C. A., MORENO-BRID, J. C. Exportaciones, términos de intercambio y ciclos de crecimiento económico de México y Brasil. EconoQuantum, v. 12, nº 1, p. 71-95, 2016.

FUJII, G.; CERVANTES, R. Valor añadido en las exportaciones manufactureras de México. CEPAL Review, 110, 2013.

GUO, D., HEWINGS, G., SONIS, M. Integrating Decomposition Approaches for the Analysis of Temporal Changes in Economic Structure: An Application to Chicago's economy from 1980 to 2000. Economic Systems Research, v, 17, p. 297-315, 2005.

HAGGARD, S. Pathways from periphery: the politics of growth in the newly industrializing countries. Nova Iorque: Cornell University Press, 1990.

HERMIDA, C. C. Padrão de especialização comercial e crescimento econômico do Brasil no contexto da fragmentação da produção e das cadeias globais de valor. 2016. 287 f. Tese (Doutorado em Economia) - Faculdade de Economia, Universidade Federal de Uberlândia, Minas Gerais.

HEWINGS, G. et al. The hollowing-out process in the Chicago economy, 1975-2011. Geographical Analysis, 30, p. 217-233, 1998. 
HIRSCHMAN, A. La estrategia de desarrollo económico. México: Fondo de Cultura Económica, 1961.

IBARRA, D., MORENO-BRID, J. C. Currency boards and monetary unions: the road ahead or a cul de sac for Mexico's exchange rate policy? In: PUCHET, M., PUNZO, L. (Orgs.). Mexico beyond NAFTA: perspectives for the European debate. Londres e Nova York: Routledge, 2001.

KATZ, J. Reformas estructurales, productividad y conducta tecnológica en América Latina. México: Fondo de Cultura Económica e CEPAL, 2000.

KUPFER, D. A indústria brasileira após a abertura. In: CASTRO, A.C. et al. (Orgs.). Brasil em desenvolvimento: economia, tecnologia e competitividade. Rio de Janeiro: Civilização Brasileira, 2005.

KUPFER, D. et al. Different Partners, Different Patterns: Trade and Labour Market Dynamics in Brazil's Post-Liberalisation Period. OECD Trade Policy Papers, Nº 149, OECD Publishing, 2013.

LANTNER, R.; LEBERT, D. Dominance, dependence and interdependence in linear structures: a theoretical model and an application to the international trade. Documents de travail du Centre d'Economie de la Sorbonne, no 43, 2013.

Économie Apliquée, v. 68, no 3, 2015.

Dominance et amplification des influences dans les structures linéaires.

LEONTIEF, W. Análisis económico input-output. Barcelona: Ediciones Orbis, 1985.

LÓPEZ J. G. La macroeconomía de México: el pasado reciente y el futuro possible. Ciudad de México: Miguel Ángel Porrua, 1998.

MARCONI, N. Estrutura produtiva e desenvolvimento econômico. In : BARBOSA, N. et al. (Orgs). Indústria e desenvolvimento produtivo. Rio de Janeiro : Elsevier e Fundação Getúlio Vargas, 2015.

MEDEIROS, C. Integração Produtiva: A Experiência Asiática e Algumas Referencias para o Mercosul. In: Integração Produtiva - caminhos para o Mercosul. Série Cadernos da Indústria, ABDI, v. 36, Brasília. 2010.

MEDEIROS, C., TREBAT, N. Finance, trade, and income distribution in global value chains: implications for developing economies and Latin America. Instituto de Economia - Texto para Discussão - , nº 002, 2017.

MORENO-BRID, J. C., ROS, J. Desarrollo y crecimiento em la economía mexicana: una perspectiva histórica. México: Fondo de Cultura Económica e CEPAL, 2010.

POLLARD, S. Peaceful Conquest: The Industrialization of Europe 1760-1970. Oxford, United Kingdom: Oxford University Press, 1981.

ROMERO, I., DIETZENBACHER, E. HEWINGS, G. Fragmentation and complexity: analyzing structural change in the Chicago regional economy. Revista de Economía Mundial, $n^{\circ}$ 23, p. 263 282, 2009.

ROS, J. Mexico's trade and industrialization experience since 1960: a reconsideration of past policies and assessment of current reforms. In: HELLEINER, G. (Org.). Trade policy and industrialization in turbulent times. New York: Routledge, 1994.

Grandes problemas: ¿Cómo salir de la trampa del lento crecimiento y alta desigualdad?. México: El Colégio de México e Universidad Nacional Autónoma de México, 2015.

RUIZ-NÁPOLES, P. Exports, growth and employment in Mexico, 1978-2000. Journal of Post Keynesian Economics, Vol. 27, no.1, p.105-124, 2004.

SARTI, F., HIRATUKA, C. Indústria mundial: mudanças e tendências recentes. Texto para Discussão: IE/UNICAMP, nº186, 2010.

TIMMER, M. et al. Patterns of structural change in developing countries. CGDC Research Memorandum, $\mathrm{n}^{\circ}$ 149, 2014.

TORRACCA, J., CASTILHO, M. The competitiveness of Brazilian manufacturing in both domestic and international markets. In: 23rd International Input-Output Association (IIOA) Conference Ciudad de México - México, 2015. 